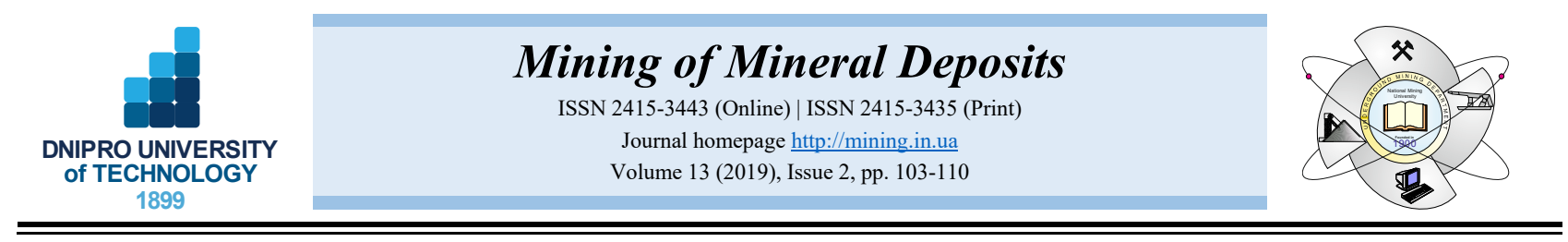

UDC 504.3:502.3

https://doi.org/10.33271/mining13.02.103

\title{
ASSURANCE OF GUARANTEED ATMOSPHERE AIR QUALITY FOR A POINT EMISSION SOURCE
}

\author{
S. Polishchuk ${ }^{1}$, V. Falko ${ }^{2}$, A. Polishchuk ${ }^{3}$, A. Demydenko ${ }^{*}$ \\ ${ }^{1}$ Prydniprovsk State Academy of Civil Engineering and Architecture, Dnipro, Ukraine \\ ${ }^{2}$ Sumy State University, Sumy, Ukraine \\ ${ }^{3}$ Ukrainian State University of Chemical Technology, Dnipro, Ukraine \\ ${ }^{4}$ Dnipro City Council, Dnipro, Ukraine \\ *Corresponding author: e-mail asdemydenko@gmail.com,tel.+380979432444
}

\begin{abstract}
Purpose. To solve the task of assessing the components of the guaranteed atmosphere air quality $P_{M P j}, P_{M P}$ depending the maximum pollutant concentrations for a point source of emissions at the stage of designing in various industries (mining, metallurgical, chemical, electric power and others).

Methods. The distribution of pollutant concentrations is represented as a vector random field, which at a given point of the area is turned into a vector random variable of concentrations and is characterized by a multi-dimensional density of distribution. To determine the density, the mathematical Berland's model of the concentrations distribution is applicable in Ukraine, in which the concentration arguments (design parameters of the source and environmental characteristics) are considered as random variables. Having assumed that the distribution density follows the normal law, using the method of function linearization of the random arguments based on the limit theorems of probability theory, its numerical characteristics have been obtained: mathematical expectations of concentrations, its mean square deviations, and correlation coefficients between concentrations.

Findings. A new concept has been introduced of guaranteed air quality for populated areas. Based on predictive assessment, the studies have been carried out to ensure it at the stage of designing the facilities that have a point source of pollutant emissions. In accordance with the methodology, a mathematical model of the task of assessing and ensuring the guaranteed quality of atmosphere air has been obtained. According to the determination of the guaranteed atmosphere air quality, its measure is presented as a multi-dimensional probability integral of non-exceedance by the concentrations of at least one pollutant of its maximum one-time permissible concentrations with obtaining the numerical characteristics.

Originality. As a result of studies, a mathematical model has been developed for the first time of the task of assessing and ensuring the guaranteed quality of atmosphere air, characterized by the probability values $P_{M P}, P_{M P j}$, when it is polluted by emissions from a point source. The control of the probability value $P_{M P}$ is performed by selecting the design source parameters so that its value is close to 1.

Practical implications. The implementation of the developed model in construction projects with high probability, close to 1 , ensures that at least one pollutant by its concentration will not exceed its normative maximum one-time permissible concentration, that is not implemented now. According to the maximum permissible concentration $M P C_{M P j}$, determination, it is guaranteed the absence of the pollution effect on a person and the occurrence of corresponding diseases.
\end{abstract}

Keywords: pollution, concentration, atmosphere air, guaranteed quality

\section{INTRODUCTION}

The global character of environmental pollution extent has already reached almost a critical level. Annually, a large number of various substances, each of which is dangerous both to living organisms and damages valua- ble property (buildings, structures, pavements, etc.), are emitted into the atmosphere.

Among the environmental problems, a special place is occupied by the problem of atmosphere air quality. This is primarily conditioned by its exceptional value for all living things on the Earth, by the influence of the

(C) 2019. S. Polishchuk, V. Falko, A. Polishchuk, A. Demydenko. Published by the Dnipro University of Technology on behalf of Mining of Mineral Deposits. This is an Open Access article distributed under the terms of the Creative Commons Attribution License (http://creativecommons.org/licenses/by/4.0/), which permits unrestricted reuse, distribution, and reproduction in any medium, provided the original work is properly cited. 
atmosphere state on the global climate processes and the biosphere as a whole due to the enormous air masses mobility, with which harmful contaminants can be transferred (Tebbens, 1966; Marlow \& Feiner, 1967; Yerramilli, Rao Dodla, \& Yerramilli, 2011; Venkatadri \& Padma, 2014). Air quality is not just a local problem. According to the UN Convention on Long-range Transboundary Air Pollution, the air pollution issues are today of global nature. Therefore, air pollution issues are important and relevant to support sustainable development and a clean environment (Pal \& Khan, 1990; Fiore, Naik, \& Leibensperger, 2015).

The quality and pollution of the air, as well as its impact on the environment, especially with regard to human health, is a problem causing serious public concern and that of many governments. The air quality study in both anthropogenic and natural pollution is carried out by scientists from many countries. In the $1960 \mathrm{~s}-1970 \mathrm{~s}$, most of the developed countries introduced into the project activity the environmental influence assessment procedure, "Environmental Impact Assessment", which is based on the assessment of the current environmental state of the area, its prediction for the design-basis time interval, and the development of alternative townplanning options by the criterion of normalization of living conditions of the population (Heller, Schueneman, \& Williams, 1966; Pearson \& Dammkoehler, 1978; Hulevets, Kokhan, \& Sharavara, 2016). With respect to the air quality in cities, the main focus of the study is on large industrial centers, but such studies are also conducted for cities that do not have developed industries.

Atmosphere air is one of those environment components on which the state of human health depends. With each breath, we breathe in the required oxygen along with small amount of potentially harmful gases and small particles. These components have a direct influence on our health, even if we are not conscious of it. The studies evidence that adverse health consequences occur not only as a result of acute events, but also as a result of chronic exposure, which reduces the expected lifespan by an average of more than eight months and more than by two years in the most polluted cities and regions of the world (Feldstein, 1969; Dhar, Pal, \& Sinha, 1991; Lee, Ferguson, \& Scott, 2009; Venkatadri \& Padma, 2014; Evaluación de la calidad..., 2017).

Nine out of ten people in the world are breathing polluted air. Most of the 7 million of people deaths in the world can be prevented. In most cities, the level of air pollution exceeds the air quality indicators recommended by World Health Organization. About one third of all deaths from stroke, lung cancer and cardiovascular diseases are caused by air pollution (Larsen, 1970; Yavorska \& Ikonnikov, 2010; Evaluación de la calidad..., 2017).

The high level of concentration of industry and agriculture, unfavorable economic activities have led to the fact that Ukraine for the moment is one of the most environmentally unfriendly countries in Europe. Today, by numerous hygienic studies, a link has been established between the concentrations of harmful emissions into the atmosphere of cities and the incidence of diseases of the respiratory organs, cardiovascular system, digestive organs, blood-forming organs, skin, al- lergies, as well as mortality. In Ukraine, almost every fifth death from infections of the lower respiratory tract is caused by air pollution.

Data on the quality, composition and characteristics of harmful substances, entering the atmosphere, are necessary primarily to determine measures to reduce pollution from operating and projected industrial enterprises. This is necessary to take them into account when drawing up development plans, including pre-plan assessments of nature protection schemes and regional planning, as well as to predict the level of air pollution in cities both for the nearest and for a long term period and, finally, to assess the damage caused to the national economy by environmental pollution by harmful substances, etc. (Rim \& Novoselac, 2010; Vasenko et al., 2015).

The air quality prediction is becoming necessary to minimize environmental disorders in the further effective air pollution control. Given this, an analysis of the main methods for predicting the air pollution has been undertaken for an effective air quality assessment (Athanasiadis, Karatzas, \& Mitkas, 2006; Venkatadri \& Padma, 2014).

The work (Bilyk, Polishchuk, Poltoratska, \& Falko, 2018) introduces the concept of guaranteed atmosphere air quality when it is polluted by emissions from various sources. This is a quality at which, with a high probability $\mathrm{P}$, the non-exceedance is ensured by the maximum or average daily concentration of at least one pollutant of its normative maximum one-time $\left(M P C_{M P}\right)$ or average daily maximum permissible concentration $\left(M P C_{C D}\right)$.

In particular, the components of guaranteed quality have been distinguished:

- guaranteed quality for individual $j$-th pollutants $(j=1, n)$ with maximum concentrations $C_{M j}$, which by value have a high probability (close to 1) $P_{M P j}$ of nonexceedance $M P C_{M P j}$;

- guaranteed quality in $n 3 P$ system with maximum concentrations $\left(C_{M 1}, C_{M 2} \ldots, C_{M n}\right)$ in the air, which by value have a high probability (close to 1) $P_{M P}$ of nonexceedance by the concentration of at least one pollutant of its $M P C_{M P j}$.

The air quality control and management is performed as at the stage of designing the facilities with emission sources (by calculating (The method of calculating..., 1987), and at the operational stage (according to measurements in environmental monitoring). In the work (Bilyk, Polishchuk, Poltoratska, \& Falko, 2018), the general task of assessing the guaranteed quality of atmosphere air was formulated, but the solution to this task is given only for the stage of facilities operation.

The purpose of the study is to solve the task of assessing the components of the guaranteed quality of atmosphere air $P_{M P j}, P_{M P}$ depending the maximum concentrations of pollutants for a point source of emissions at the stage of designing.

\section{METHODS}

The stationary sources of pollutant emissions are widely used in various industries (metallurgical, chemical, electric power and others). Such sources that disperse pollutants in the atmosphere and thereby provide permissible substances concentrations in the surface layer of the atmosphere are considered as point sources 
(The method of calculating..., 1987). In the mining industry, such sources are used for emission of pollutants in course of mining operations (Sarycheva, 2003; Gorova, Pavlychenko, Kulyna, \& Shkremetko, 2012; Gorova, Pavlychenko, Borysovs'ka, \& Krups'ka, 2013).

Based on the stochastic approach (Falko, Polishchuk, $\&$ Tokovenko, 2014) the concentrations $n 3 P\left(C_{M j}\right.$, $j=1, n)$ are considered as random variables. The distribution of pollutants around the source of emission is represented in the form of a vector random field, which at a given point of the area is turned into a vector random variable (Yadrenko, 1974). Such a field at this point is characterized by $n$-dimensional density of a random concentrations distribution (Knox \& Lange, 1974; Venttsel, 1998; Hopke, 2008).

Using the method of function linearization from the random arguments based on the limit theorems of probability theory, assuming that the distribution density follows the normal law, (Venttsel, 1998), its numerical characteristics have been obtained: mathematical expectations $C_{j}^{*}, j=1, n$ of pollutant concentrations, their mean square deviations $\sigma_{j}, j=1, n$ and correlation coefficients $r_{j i}, j=1, n ; j \neq i$ between the concentrations of $j$-th and $j$-th pollutants.

By determination, the guaranteed atmosphere air quality is represented as $n$-dimensional $P_{M P}$ probability integral of non-exceedance by $j$-th concentrations $C_{M j}$ of at least one pollutant of its $M P C_{M P j}$, in which the subintegral function is the density of pollutant concentrations distribution with the obtained numerical characteristics. The $P_{M P I}$ probability values are determined through a one-dimensional integral.

In accordance with the methodology, a mathematical model of the task of assessing and ensuring the guaranteed quality of atmosphere air has been obtained.

The determination of the numerical characteristics of vector random variables of pollutant concentrations was performed with the use of the linearization method for the deterministic mathematical Berland's model, the distribution of $C_{M j}$ concentrations in the surface layer of the atmosphere from a point source of emissions (Berliand, 1985; The method of calculating..., 1987).

\section{RESEARCH RESULTS}

The air pollution is caused by emissions of mass $M_{j}$ of various $j=i, n$ pollutants. Based on this, the mathematical Berland's model is represented as a function from the pollutant emissions mass:

$C_{j}\left(M_{j}\right)=b_{j} M_{j}+C_{\phi j}+\Delta C_{j}$,

where:

$$
b_{j}=\frac{A F_{j} m n \eta}{H^{2} \sqrt[3]{\frac{\pi D^{2}}{4} \omega_{0\left(T_{r}-T_{b}\right)}}} r(u) S_{1 j}(x) S_{2}(x, y) ;
$$

$A$ - coefficient which depends on the temperature atmosphere stratification and determines the conditions for the vertical and horizontal dispersion of harmful substances in the atmosphere air;
$M_{j}$ - mass of the $j$-th pollutant emitted into the atmosphere per time unit, gram per second;

$F_{j}$-dimensionless coefficient which takes into account the sedimentation rate of the $j$-th harmful substance in the atmosphere air;

$H$ - height of emission source above ground level, m;

$T_{r}$ - temperature of emitted gas/air mixture, ${ }^{\circ} \mathrm{C}$;

$T_{b}$ - ambient air temperature, ${ }^{\circ} \mathrm{C}$;

$D$ - diameter of the emission source mouth, m;

$\omega_{0}$-average rate of the gas-air mixture emission from the emission source mouth, $\mathrm{m} / \mathrm{sec}$;

$m$ and $n$-dimensionless coefficients which take into account the conditions for the gas-air mixture emission from the emission source mouth, and are dependent on $\omega_{0}, D, H, T_{r}, T_{b}$;

$\eta$-dimensionless coefficient which takes into account the influence of the terrain relief (in the case of flat or moderate terrain with a difference in height not exceeding $50 \mathrm{~m}$ per $1 \mathrm{~km}, \eta=1)$;

$r(u)$-coefficient which takes into account the influence of wind speed $u$;

$S_{1}(x), S_{2}(x, y)$-coefficients which take into account the changes in the distance $x$ from the source along the plume centreline, $y$-along the perpendicular to the $x$ plume centreline in the horizontal plane.

$C_{\phi j}$ - background concentration;

$\Delta C_{j}$ - concentration determination error.

In order to consider the influence of a change in the azimuth of the wind speed vector, it is accepted that for a point, which is located along the wind direction at a distance $R$ from the source, a change in the wind azimuth by an angle $\varphi$ causes a change in coordinates $x=R \cos \varphi$, $y=R \sin \varphi$.

Based on the stochastic approach, the concentrations $C_{M j}$ are considered as functions of random arguments of the design parameters of the source (and characteristics of the external environment):

$$
C_{M j}=C_{M j}\left(\lambda_{1 j}, \lambda_{2 j}, \lambda_{3 j}, \lambda_{4 j}, \lambda_{5}, \ldots, \lambda_{q}, \ldots, \lambda_{m}\right)
$$

where:

$$
\begin{aligned}
& \lambda_{1 j}=M_{j} ; \lambda_{2 j}=F_{j} ; \lambda_{3 j}=\Delta C_{\phi j} ; \lambda_{5}=A ; \lambda_{6}=\omega_{0} \\
& \lambda_{7}=D ; \lambda_{8}=H ; \lambda_{9}=T_{r} ; \lambda_{10}=T_{\pi} ; \lambda_{11}=\eta \\
& \lambda_{12}=u ; \lambda_{13}=\varphi ; \lambda_{14}=x ; \lambda_{15}=y .
\end{aligned}
$$

Assuming that the random variables $\lambda_{q}$ are independent, and given that the concentrations $C_{M j}$ for different pollutants depend on a part of independent $(q=1,2,3$, $4)$, and on a part of the same random variables $(q=5, \ldots$, $m$ ), using conventional methods of probability theory and linearization, the main numerical characteristics of the distribution law of the system of random variables $C_{j}$ of concentrations are presented in the following form:

a) mathematical expectations:

$C_{M j}=C_{j}\left(\lambda_{1 j}, \lambda_{2 j}, \lambda_{3 j}, \lambda_{4 j}, \ldots \lambda_{m}\right) ;$

b) mean square deviations:

$$
\sigma_{j}=\sqrt{\sum_{q=1}^{4}\left(\frac{\partial C_{M j}}{\partial \lambda_{q j}} * \sigma_{q j}\right)^{2}+\sum_{q=5}^{m}\left(\frac{\partial C_{M j}}{\partial \lambda_{q}} * \sigma_{q}\right)^{2}} ;
$$


c) correlation moments $K_{j p}$ and correlation coefficients $r_{j p}$ between the $j$-th and $j$-th concentrations of pollutants:

$$
K_{j p}=\sum_{q=5}^{m} \frac{\partial C_{M j}}{\partial \lambda_{q}} \cdot \frac{\partial C_{M i}}{\partial \lambda_{q}} \sigma_{q}^{2}, \quad r_{j i}=\frac{K_{j i}}{\sigma_{j} \cdot \sigma_{i}},
$$

where:

$\lambda_{q j}, \lambda_{q}, \sigma_{1 j}, \sigma_{2 j}, . ., \sigma_{m}$ - mathematical expectations and mean square deviations of random variables $\lambda_{q j}, \lambda_{q}$;

$\partial C_{M j} / \partial \lambda_{q j}, \partial C_{M j} / \partial \lambda_{q}$ - partial derivatives of concentration by random variables $\lambda_{q j}, \lambda_{q}$.

The derivatives $\partial C_{M j} / \partial \lambda_{q j}, \partial C_{M j} / \partial \lambda_{q}$ take into account in the first approximation the disturbing factors influence on the concentration $C$ of pollutants.

Having determined and substituted them into (4) and (5), after simple transformations, the mean square deviations of the pollutant concentrations are represented in the form (6):

$$
\begin{aligned}
& \sigma_{j}\left(M_{j}\right)=\left({ }_{1 j}^{2} b_{j}^{2} M_{j}^{2}+\left(b_{j} \sigma_{C o j}{ }^{2}\right)+\right. \\
& \left.A{\sigma_{C_{o j}}}^{2}+\sigma_{\Delta C_{o j}}{ }^{2}\right)^{\frac{1}{2}} .
\end{aligned}
$$

Here, the value $A_{1 j}$ takes into account the influence of random deviations of the corresponding design parameters and external environment characteristics $\lambda_{k j}, \lambda_{k}$ through their specified mean square deviations $\sigma_{\lambda k j}, \sigma_{\lambda k}$, and has the form:

$$
\begin{aligned}
& A_{1 j}{ }^{2}=\frac{\sigma A^{2}}{A^{2}}+\left(\frac{1}{F_{j}}+\frac{1}{S_{1 j}} \cdot \frac{\partial S_{1 j}}{\partial F_{j}}\right)^{2} \sigma_{F j}{ }^{2}+\frac{\sigma \eta^{2}}{\eta^{2}}+ \\
& +\left(\frac{1}{r} \cdot \frac{\partial r}{\partial u}+\frac{1}{S_{2}} \cdot \frac{\partial S_{2}}{\partial u}\right)^{2} \sigma_{u}{ }^{2}+400 u^{2} S_{2} \varphi^{2} \sigma_{\varphi}{ }^{2}+ \\
& +\left(\frac{1}{S_{q j}} \cdot \frac{\partial S_{1 j}}{\partial x}+\frac{1}{S_{2}} \cdot \frac{\partial S_{2}}{\partial x}\right) \sigma_{x}{ }^{2}+\left(\frac{1}{S_{2}} \cdot \frac{\partial S_{2}}{\partial y} \sigma_{y}\right)^{2}+ \\
& +a_{H j}{ }^{2} \sigma_{H}{ }^{2}+a_{D j}{ }^{2}{\sigma_{D}}^{2}+a_{w j}{ }^{2} \sigma_{w o}{ }^{2}+a_{T r}{ }^{2}\left(\sigma_{T r}^{2}+\sigma_{T_{B}}{ }^{2}\right),
\end{aligned}
$$

where:

$$
\begin{aligned}
& a_{H j}=\left(-\frac{2}{H}+\frac{1}{m} \cdot \frac{\partial m}{\partial H}+\frac{1}{n} \frac{\partial n}{\partial H}+\frac{1}{\eta} \frac{\partial r}{\partial H}+\frac{1}{S_{1 j}} \cdot \frac{\partial S_{q j}}{\partial H}\right) ; \\
& a_{D j}=\left(-\frac{2}{3 D}+\frac{1}{m} \cdot \frac{\partial m}{\partial D}+\frac{1}{n} \frac{\partial n}{\partial D}+\frac{1}{\eta} \frac{\partial r}{\partial w_{o}}+\frac{1}{S_{1 j}} \cdot \frac{\partial S_{q j}}{\partial D}\right) ;
\end{aligned}
$$

$$
\begin{aligned}
& a_{w_{o j}}=\left(-\frac{1}{3 w_{o}}+\frac{1}{m} \cdot \frac{\partial m}{\partial w_{o}}+\frac{1}{n} \frac{\partial n}{w_{o}}+\frac{1}{r} \frac{\partial r}{\partial w_{o}}+\frac{1}{S_{1 j}} \cdot \frac{\partial S_{q j}}{\partial w_{o}}\right) \\
& a_{T_{r}}=\left(-\frac{1}{3\left(T_{r}-T_{b}\right)}+\frac{1}{m} \frac{\partial m}{\partial T_{r}}+\frac{1}{n} \frac{\partial n}{T_{r}}+\frac{1}{r} \frac{\partial r}{\partial T_{r}}+\frac{1}{S_{1 j}} \cdot \frac{\partial S_{q j}}{\partial T_{r}}\right)
\end{aligned}
$$

in accordance with (The method of calculating..., 1987; Berliand, 1985), the dimensionless coefficients $m$ and $n$ are determined through functions $f, f_{b}, v_{m}, v_{m}^{\prime}$. Then, having denoted $\xi_{1}=f, \xi_{2}=f_{b}$ and $\varphi_{1}=v_{m}, \varphi_{2}=v^{\prime}{ }_{m}$ the derivatives from $m$ and $n$, included into (7), are represented in general form:

$$
\frac{\partial m}{\partial \lambda_{k}}=\frac{\partial m}{\partial \xi_{i}} \cdot \frac{\partial \xi_{i}}{\partial \lambda_{k}} ; \quad \frac{\partial n}{\partial \lambda_{k}}=\frac{\partial n}{\partial \varphi_{i}} \cdot \frac{\partial \varphi_{i}}{\partial k} .
$$

Their calculation results are presented in Tables $1-3$.

The rest of the derivatives included into (7), which is presented in (Falko, Polishchuk, \& Tokovenko, 2014), and due to the big volume of material, are not presented here.

Having substituted the obtained derivatives into (5), the correlation coefficient has been obtained in the form:

\begin{tabular}{|c|c|c|c|}
\hline \multirow{2}{*}{ Derivatives } & \multicolumn{3}{|c|}{ Values $f, f_{b}$} \\
\hline & $f \leq f_{b}$ & $f_{b}<f \leq 100$ & $f>100$ \\
\hline$\frac{\partial m}{\partial f}$ & $-m^{2}\left(0.05 f^{-1 / 2}+0.1133 f^{-2 / 3}\right)$ & 0 & $-\frac{m}{3 f}$ \\
\hline$\frac{\partial m}{\partial f_{e}}$ & 0 & $-m^{2}\left(0.05 f^{-1 / 2}+0.1133 f^{-2 / 3}\right)$ & 0 \\
\hline
\end{tabular}

$r_{j i}=\frac{B_{j i}}{A_{1 j} \cdot A_{1 i}}$,

where:

$$
\begin{aligned}
& B_{j i}=\frac{\sigma_{A}{ }^{2}}{A^{2}}+\frac{\sigma_{\eta}{ }^{2}}{\eta^{2}}\left(\frac{1}{r} \cdot \frac{\partial r}{\partial u}+\frac{1}{S_{2}} \cdot \frac{\partial S_{2}}{\partial u}\right)^{2} \sigma_{u}{ }^{2}+ \\
& +400 u^{2} S_{2} \cdot \varphi^{2} \cdot \sigma_{\varphi}{ }^{2}+\left(\frac{1}{S_{1 j}} \cdot \frac{\partial S_{1 j}}{\partial x}+\frac{1}{S_{2}} \cdot \frac{\partial S_{2}}{\partial x}\right) \times \\
& \times\left(\frac{1}{S_{1 i}} \cdot \frac{\partial S_{1 i}}{\partial x}+\frac{1}{S_{2}} \cdot \frac{\partial S_{2}}{\partial x}\right) \sigma_{x}^{2}+\left(\frac{1}{S_{2}} \cdot \frac{\partial S_{2}}{\partial y}\right) \sigma_{y}{ }^{2}+ \\
& +a_{H j} \cdot a_{H i} \cdot \sigma_{H}{ }^{2}+a_{D j} \cdot a_{D j} \sigma_{D}{ }^{2}+a_{w_{o j}} \cdot a_{w_{o i}} \times \\
& \times \sigma_{w_{o}}{ }^{2}+a_{T_{a}} \cdot a_{T_{a}}\left({\sigma_{T_{r}}}^{2}-\sigma_{\pi}{ }^{2}\right) .
\end{aligned}
$$

The numerical characteristics $C_{M i}{ }^{*}, \sigma_{i}, r_{j i}$ determine the one-dimensional $\left(C_{j}\right), j=\overline{i, n}$ densities of the concentrations distribution, which follow the onedimensional normal law:

$f\left(C_{j}\right)=\frac{1}{\sigma_{j} \sqrt{2 \lambda}} e^{-\frac{\left(C_{M j}-C_{M j}^{*}\right)}{2 \sigma_{j}^{2}}}$.

Table 1. Derivatives $\frac{\partial m}{\partial f}, \frac{\partial m}{\partial f_{e}}$ 
Table 2. Derivatives $\frac{\partial n}{\partial \vartheta_{m}}, \frac{\partial n}{\partial v_{m}^{i}}$

\begin{tabular}{cccc}
\hline & & \multicolumn{2}{c}{ Derivatives } \\
\cline { 2 - 4 } Values $f, \theta_{M}$ & $\frac{\partial n}{\partial \vartheta_{m}}$ & $\frac{\partial n}{\partial v_{m}^{i}}$ \\
\hline \multirow{2}{*}{$f<100$} & $0.5 \leq \vartheta_{m}<2$ & 0 & 0 \\
& $\vartheta_{m}<0.5$ & $1.064 \cdot \vartheta_{m}-2.13$ & 0 \\
\hline \multirow{2}{*}{$f>100$} & $v_{m}^{i} \geq 2$ & 4.4 & 0 \\
or & $0.5 \leq v_{m}^{i} \leq 2$ & 0 & 0 \\
$\Delta T \approx 0$ & $v_{m}^{i} \leq 0.5$ & 0 & $1.064 \cdot v_{m}^{i}-2.13$ \\
\hline
\end{tabular}

Table 3. Derivatives $\frac{\partial \xi}{\partial \lambda_{k}}\left(\xi=\vartheta_{n v}, f, v_{m}^{i}, f_{e}\right)$

\begin{tabular}{ccccc}
\hline$\lambda_{k}$ & $\frac{\partial \vartheta_{m}}{\partial \lambda_{k}}$ & $\frac{\partial f}{\partial \lambda_{k}}$ & $\frac{\partial v_{m}^{i}}{\partial \lambda_{k}}$ & $\frac{\partial f_{e}}{\partial \lambda_{k}}$ \\
\hline$H$ & $\frac{-\vartheta_{m}}{3 H}$ & $-\frac{2 f}{H}$ & $\frac{-v_{m}^{i}}{H}$ & $\frac{-3 f_{e}}{H}$ \\
$D$ & $\frac{2 \vartheta_{m}}{3 D}$ & $\frac{f}{D}$ & $\frac{v_{m}^{i}}{D}$ & $\frac{3 f_{e}}{D}$ \\
$\omega_{0}$ & $\frac{\vartheta_{m}}{3 \omega_{o}}$ & $\frac{2 f}{\omega_{o}}$ & $\frac{v_{m}^{i}}{\omega_{o}}$ & $\frac{3 f_{e}}{w_{o}}$ \\
$T_{g}$ & $\frac{\vartheta_{m}}{3\left(T_{r}-T_{\pi}\right)}$ & $\frac{-f}{\left(T_{r}-T_{\pi}\right)}$ & 0 & 0 \\
$T_{p}$ & $\frac{-\vartheta_{m}}{3\left(T_{r}-T_{\pi}\right)}$ & $\frac{f}{\left(T_{r}-T_{\pi}\right)}$ & 0 & 0 \\
\hline
\end{tabular}

For multi-dimensional density:

$f\left(C_{M_{1}}, C_{M_{2}}, \ldots, C_{M_{i}}, \ldots, C_{M_{n}}\right)$,

which follows the multi-dimensional normal law.

By determination, the guaranteed atmosphere air quality for individual $j$-th pollutants with $C_{M i}$ concentrations is determined through a one-dimensional integral:

$P_{M P j}=\frac{1}{\sqrt{2 \lambda}} \int_{-\infty}^{t} e^{-\frac{t^{2}}{2} d t}$,

where:

$$
t=\frac{C_{M j}-C_{M j}{ }^{*}}{\sigma_{j}} .
$$

The work (Venttsel, 1998) represents it in the form of a table, and there is a standard PC program to determine it.

The guaranteed quality in the system $n 3 P$ with maximum concentrations $\left(C_{M_{1}}, C_{M_{2}}, \ldots, C_{M_{n}}\right)$ in the atmosphere air are determibed through a multidimensional integral:

$$
P_{M P}=\int_{-\infty}^{M P C_{M P_{1}}} \ldots \int_{-\infty}^{M P C_{M o n}} f\left(C_{1}, C_{2}, \ldots C_{n}\right) d c, \ldots d C_{n} .
$$

For large numbers $\mathrm{n}$, to prevent computational difficulties, the approximate integral value is used (17), which is offered in (Falko, Polishchuk, \& Tokovenko, 2014):

$P_{M P}=\mu P_{M P}^{\min }+(1-\mu) \Pi_{j=1}^{n} P_{M P j}$,

where:

$$
\begin{aligned}
& P_{M P}{ }^{\min }={ }_{j}^{\min } P_{M P j} ; \\
& \mu=\frac{1}{\lambda(n-1) n} \sum_{i \neq j} \sum_{j} \operatorname{arc~sin} r_{j i} .
\end{aligned}
$$

The mathematical model of the task of assessing the guaranteed atmosphere air quality $P_{M P}$ includes equations (1) - (16).

If the probability $P_{M P}$, when solving the task is small, then it reaches a value close to 1 by selecting the necessary design parameters of the source $M_{i}, H, T_{2}, D, x, y$. Thus, when choosing, first of all, an attention should be paid to the value $M_{i}$ of emission mass, since, by reducing this, it makes possible to reduce not only numerous concentrations, but also environmental pollution.

When developing the construction projects, the predicted guaranteed quality of the atmosphere air surface layer $P$ includes guaranteed quality for individual $j$-th pollutants, which is characterized by the probability $P_{M P i}$, as well as guaranteed quality according to the system of 
all $(j=\overline{i, n})$ pollutants, which is characterized by the probability $P_{M P}$ of non-exceedance by the concentration of at least one pollutant of its maximum one-time permissible concentration.

The control of the probability value $P_{M P}$ is performed by selecting the design source parameters so that its value is close to 1 .

As a result of studies, a mathematical model has been developed for the first time of the task of assessing and ensuring the guaranteed quality of atmosphere air, characterized by the probability values $P_{M P}, P_{M P i}$, when it is polluted by emissions from a point source.

\section{CONCLUSIONS}

The implementation of the developed model in construction projects with high probability, close to 1 , ensures that at least one pollutant by its concentration will not exceed its normative maximum one-time permissible concentration $\left(M P C_{M P j}\right)$, that is not implemented now. According to $M P C_{M P j}$ determination, it is guaranteed the absence of the pollution effect on a person and the occurrence of corresponding diseases.

The mathematical model has been obtained of the task of assessing and ensuring the predictable components of the guaranteed atmosphere air quality in the surface layer when it is polluted with a point source of emissions. The impementation of the developed model in construction projects ensures with high probability, close to 1 , the absence of the pollution effect on a person and the occurrence of corresponding diseases, that is not implemented now.

\section{ACKNOWLEDGEMENTS}

The work has been performed without the financial support of any grant or a scientific project. The authors express their gratitude to reviewers for relevant comments and recommendations on improving the article quality.

\section{REFERENCES}

Athanasiadis, N., Karatzas, K., \& Mitkas, P. (2006). Classification techniques for air quality forecasting Ioannis. European Conference on Artificial Intelligence. Italy: Riva del Garda.

Berliand, M.E. (1985) Prediction and regulation of air pollution. Moscow, Russian Federation: Hydrometeoizdat.

Bilyk, Y., Polishchuk, S., Poltoratska, V., \& Falko, V. (2018). The concept of guaranteed air quality and its assessment. Energy, Ecology, Life Safety and Computer Technologies in Construction.

Dhar, R., Pal, D., \& Sinha, D. (1991). On a numerical model of dispersion of chemically reactive pollutants from a point source. International Journal of Environmental Studies, 39(3), 189-201. https://doi.org/10.1080/00207239108710694

Evaluación de la calidad del aire en España. (2017). Madrid, España: Ministerio para la transición ecologica.

Falko, V.V., Polishchuk, S.Z., \& Tokovenko, A.V. (2014). Ecological risk for a person from air pollution. Dnipropetrovsk: Economy.

Feldstein, M. (1969). Editorial: air pollution. Clinical Toxicology, 2(3), 303-305.

https://doi.org/10.3109/15563656908990937
Fiore, A., Naik, V., \& Leibensperger, E. (2015). Air quality and climate connections. Journal of the Air \& Waste Management Association, 65(6), 645-685. https://doi.org/10.1080/10962247.2015.1040526

Gorova, A., Pavlychenko, A., Kulyna, S., \& Shkremetko, O. (2012). Ecological problems of post-industrial mining areas. Geomechanical Processes During Underground Mining Proceedings of the School of Underground Mining, 35-40. https://oi.org/10.1201/b13157-7

Gorova, A., Pavlychenko, A., Borysovs'ka, O., \& Krups'ka, L. (2013). The development of methodology for assessment of environmental risk degree in mining regions. Annual Scientific-Technical Collection - Mining of Mineral Deposits 2013, 207-209. https://doi.org/10.1201/b16354-38

Heller, A.N., Schueneman, J.J., \& Williams, J.D. (1966). The air resource management concept. Journal of the Air Pollution Control Association, 16(6), 307-309. https://doi.org/10.1080/00022470.1966.10468476

Hopke, P.K. (2008). The use of source apportionment for air quality management and health assessments. Journal of Toxicology and Environmental Health, Part A, 71(9-10), 555-563. https://doi.org/10.1080/15287390801997500

Hulevets, D., Kokhan, O., \& Sharavara, V. (2016). Assessment of the quality of atmospheric air and its method of visualization for solving ecological safety problems. First Independent Scientific Journal, 88-94.

Knox, J.B., \& Lange, R. (1974). Surface air pollutant concentration frequency distributions: implications for urban modeling. Journal of the Air Pollution Control Association, 24(1), 48-53. https://doi.org/10.1080/00022470.1974.10469893

Larsen, R.I. (1970). Relating air pollutant effects to concentration and control. Journal of the Air Pollution Control Association, 20(4), 214-225. https://doi.org/10.1080/00022470.1970.10469394

Lee, D., Ferguson, C., \& Scott, E.M. (2009). Air quality indicators in health studies. Book of short reports CLADAG 2009, CLEUP, Padua, 217-220.

Marlow, S., \& Feiner, B. (1967). Experience with the New York state air pollution control rules - industrial sources. American Industrial Hygiene Association Journal, 28(2), 184-190. https://doi.org/10.1080/00028896709342506

Pal, D., \& Khan, S. (1990). A time dependent mathematical model for dispersion of air pollutants from point sources. International Journal of Environmental Studies, 35(3), 197-208. https://doi.org/10.1080/00207239008710565

Pearson, J.R., \& Dammkoehler, A.R. (1978). Indirect source review: problems for the air pollution control agency. Journal of the Air Pollution Control Association, 28(4), 367-370. https://doi.org/10.1080/00022470.1978.10470612

Rim, D., \& Novoselac, A. (2010). Occupational exposure to hazardous airborne pollutants: effects of air mixing and source location. Journal of Occupational and Environmental Hygiene, 7(12), 683-692. https://doi.org/10.1080/15459624.2010.526894

Sarycheva, L. (2003). Using GMDH in ecological and socioeconomical monitoring problems. Systems Analysis Modelling Simulation, 43(10), 1409-1414. https://doi.org/10.1080/02329290290024925

Tebbens, B.D. (1966). Air monitoring reflects air pollution control activity. Journal of the Air Pollution Control Association, 16(5), 261-262.

https://doi.org/10.1080/00022470.1966.10468471

The method of calculating the concentration in the air of harmful substances in the emissions of enterprises. (1987). Lenynhrad: Hydrometeoyzdat. 
Vasenko, O.H., Rybalova, O.V., Artem'iev, S.R., Horban, N.S., Korobkova, H.V., Polozentsieva, V.O., Kozlovska, O.V., Matsak, A.O., \& Savichiev, A.A. (2015). Integrated environmental assessments. Kharkiv: Lira.

Venkatadri, M., \& Padma, S. (2014). A survey on air quality forecasting techniques niharika. International Journal of Computer Science and Information Technologies, 103-107.

Venttsel, E. (1998). Probability theory: studies for universities. Moscow, Russian Federation: High school.
Yadrenko, M. (1974). Random field. Encyclopedia of Energy, 376-377.

Yavorska, O., \& Ikonnikov, O. (2010). Statistical analysis of atmospheric air in Ukraine. Scientific Bulletin of NLTU of Ukraine, 83-88.

Yerramilli, A., Rao Dodla, V.B., \& Yerramilli, S. (2011). Air pollution, modeling and GIS based decision support systems for air quality risk assessment. Advanced Air Pollution, (17), 295-324.

https://doi.org/10.5772/22055

\section{ЗАБЕЗПЕЧЕННЯ ГАРАНТОВАНОЇ ЯКОСТІ АТМОСФЕРНОГО ПОВІТРЯ ДЛЯ ТОЧКОВОГО ДЖЕРЕЛА ВИКИДІВ}

\section{С. Поліщук, В. Фалько, А. Поліщук, А. Демиденко}

Мета. Рішення задачі оцінки складових гарантованої якості атмосферного повітря $P_{M P}, P_{M P}$ від максимальних концентрацій забруднюючих речовин для точкового джерела викидів на етапі проектування в різних галузях промисловості (гірничодобувній, металургійній, хімічній, енергетичній та інших).

Методика. Розповсюдження концентрацій забруднюючих речовин представлено у вигляді векторного випадкового поля, що в заданій точці місцевості перетворюється у векторну випадкову величину концентрацій і характеризується багатомірною щільністю розподілу. Для визначення щільності використана діюча в Україні математична модель розповсюдження концентрацій Берлянда, в якій аргументи концентрацій (проектні параметри джерела та характеристики навколишнього середовища) розглянуті як випадкові величини. Припускаючи, що щільність розподілу підпорядкована нормальному закону, за допомогою методу лінеаризації функції випадкових аргументів на основі граничних теорем теорії ймовірностей, отримано ії числові характеристики: математичні сподівання концентрацій, іiі середньоквадратичні відхилення, коефіцієнти кореляції між концентраціями.

Результати. Введено нове поняття гарантованої якості атмосферного повітря для населених місць. Проведені дослідження за прогнозною оцінкою для іiї забезпечення на етапі проектування об’єктів, що мають точкове джерело викидів забруднюючих речовин. Відповідно до методики, отримано математичну модель задачі оцінки і забезпечення гарантованої якості атмосферного повітря. Згідно визначення гарантованої якості атмосферного повітря іiі міра представлена як багатомірний інтеграл ймовірності неперевищення концентраціями хоча б однієї забруднюючої речовини своїх максимально разових гранично допустимих концентрацій з отриманими числовими характеристиками.

Наукова новизна. В результаті досліджень вперше розроблена математична модель задачі оцінки і забезпечення гарантованих якостей атмосферного повітря, що характеризуються величинами ймовірностей $P_{M P}, P_{M P j}$, при забрудненні його викидами від точкового джерела. Управління величиною ймовірності $P_{M P}$ виконується шляхом вибору проектних параметрів джерела так, щоб величина ії була близькою до 1.

Практична значимість. Впровадження розробленої моделі у проектах будівництва з високою ймовірністю, близькою до 1 , забезпечує відсутність перевищення концентрацією хоча б однієї забруднюючої речовини своєї нормативної максимальної разової гранично допустимої концентрації, що зараз не виконується. Відповідно до визначення ГДК МРј при цьому гарантується відсутність впливу забруднень на людину і виникнення відповідних захворювань.

Ключові слова: забруднення, концентраиії, атмосферне повітря, гарантована якість

\section{ОБЕСПЕЧЕНИЕ ГАРАНТИРОВАННОГО КАЧЕСТВА АТМОСФЕРНОГО ВОЗДУХА ДЛЯ ТОЧЕЧНОГО ИСТОЧНИКА ВЫБРОСОВ}

\section{С. Полищук, В. Фалько, А. Полищук, А. Демиденко}

Цель. Решение задачи оценки составляющих гарантированного качества атмосферного воздуха $P_{M P j}, P_{M P}$ от максимальных концентраций загрязняющих веществ для точечного источника выбросов на этапе проектирования в различных отраслях промышленности (горнодобывающей, металлургической, химической, энергетической и других).

Методика. Распространение концентраций загрязняющих веществ представлено в виде векторного случайного поля, которое в заданной точке местности превращается в векторную случайную величину концентраций и характеризуется многомерной плотностью распределения. Для определения плотности использована действующая в Украине математическая модель распространения концентраций Берлянда, в которой аргументы концентраций (проектные параметры источника и характеристики окружающей среды) рассмотрены как случайные величины. Предполагая, что плотность распределения подчинена нормальному закону, с помощью метода линеаризации функции случайных аргументов на основе предельных теорем теории вероятностей, получено ее числовые характеристики: математические ожидания концентраций, ее среднеквадратичные отклонения, коэффициенты корреляции между концентрациями.

Результаты. Введено новое понятие гарантированного качества атмосферного воздуха для населенных мест. Проведенные исследования по прогнозной оценке для ее обеспечения на этапе проектирования объектов, имеющих точечный источник выбросов загрязняющих веществ. Согласно методике, получена математическая 
модель задачи оценки и обеспечения гарантированного качества атмосферного воздуха. Согласно определению гарантированного качества атмосферного воздуха ее мера представлена как многомерный интеграл вероятности непревышения концентрациями хотя бы одного загрязняющего вещества своих максимально разовых предельно допустимых концентраций с полученными числовыми характеристиками.

Научная новизна. В результате исследований впервые разработана математическая модель задачи оценки и обеспечения гарантированных качеств атмосферного воздуха, характеризующихся величинами вероятностей $P_{M P}, P_{M P j}$, при загрязнении его выбросами от точечного источника. Управление величиной вероятности $P_{M P}$ выполняется путем выбора проектных параметров источника так, чтобы величина ее была близка к 1.

Практическая значимость. Внедрение разработанной модели в проектах строительства с высокой вероятностью, близкой к 1, обеспечивает отсутствие превышения концентрации хотя бы одного загрязняющего вещества своей нормативной максимальной разовой предельно допустимой концентрации, что сейчас не выполняется. Согласно определению ГДК мРј при этом гарантируется отсутствие влияния загрязнений на человека и возникновение соответствующих заболеваний.

Ключевые слова: загрязнения, концентраџии, атмосферный воздух, гарантированное качество

\section{ARTICLE INFO}

Received: 10 January 2019

Accepted: 17 May 2019

Available online: 7 June 2019

\section{ABOUT AUTHORS}

Serhii Polishchuk, Doctor of Technical Sciences, Professor of the Department of Heating, Ventilation and Air Quality, Prydniprovsk State Academy of Civil Engineering and Architecture, 24-a Chernyshevskoho St, 49005, Dnipro, Ukraine. E-mail: polishchuk.serhii@pgasa.dp.ua

Vira Falko, Candidate of Technical Sciences, Associate Professor of the Applied Ecology Department, Sumy State University, 2 Rymskoho-Korsakova St, 40000, Sumy, Ukraine. E-mail: vera falko@ukr.net

Alla Polishchuk, Candidate of Technical Sciences, Associate Professor of the Higher Mathematics Department, Ukrainian State University of Chemical Technology, 8 Haharina Ave., 49005, Dnipro, Ukraine. E-mail: polalvik@ukr.net

Anna Demydenko, PhD Student, Head of the Environmental Monitoring Sector of the Environmental Policy Department, Dnipro City Council, 75 Yavornytskoho Ave., 49057, Dnipro, Ukraine. E-mail: asdemydenko@gmail.com 